\title{
The Influence of Human Resource Practices on Job Satisfaction: Empirical Investigation of Jordan Hotels
}

\author{
Daifallah Olaimat \\ E-mail: Daiff76@yahoo.com
}

Received: Sep. 13, 2018 Accepted: Oct. 9, 2018 Online published: Oct. 28, 2018

doi:10.5296/ijhrs.v8i4.13644ＵRL: https://doi.org/10.5296/ijhrs.v8i4.13644

\begin{abstract}
The present study examined the influence human resource practices on job satisfaction in the context of hotel industry in Jordan. The present study used five human resource practices such as recruitment and selection, performance appraisal, training and development, compensation, and employee participation. A total of 120 responses from 8 hotels were collected and analyzed objectively. Multiple regression was used to test the hypotheses. Results showed that all practices of human resource (i.e. recruitment and selection, performance appraisal, training and development, compensation, and employee participation) had positive influence on job satisfaction.
\end{abstract}

Keywords: human resource practices, job satisfaction, hotel industry, Jordan

\section{Introduction}

In Jordan, the tourism sector is considered to be one of the most significant sectors owing to its contribution to the country's economy (13\% of GDP) and its role as the top producer of foreign exchange in the country (DOS, 2016). The primary market is focused on Arabs (the largest segment), the Europeans and the Americans. In addition, there are several economic advantages that stem from the hospitality industry; for instance, employees working in the tourism industry in Jordan, in 2015 alone, numbered 49,096, an increase from 23,544 a decade earlier (2005), from which $38.3 \%$ of the workers are employed by the hotel sector (MOTA, 2016). This notable increase in a decade span can be related to the overall growth in the hospitality industry. Even more recently, Jordan has experienced increasing growth in the tourism industry (DOS, 2016), with the number accommodations and hotels increasing with the increase of arrivals to the country. Consequently, the number of hotels in the country has increased from 200 (2000) to 490 (2010), and 573 (2015), with the number of rooms increasing from 23,882 (2010) to 28,160 (2015). Majority of the hotels are located in Amman, the capital of Jordan (383 hotels), followed by Aqaba (64 hotels), Petra (40 hotels), Irbid (18 hotels) and the Dead Sea (9 hotels) (MOTA, 2016). In fact, the hotel industry has become the 
top growing industry - similar to other developing countries, where the sector assists in resolving socio-economic issues (Holjevac, 2003). Among the fundamental characteristics of the hotel sector is its direct dependence on human components to present services to the patrons.

In this background, human resource management is important for successful organization as human capital possesses valuable qualities. With regards to the business strategy, an organization can succeed if it obtains sustainable competitive advantage indicating that it is superior to its rivals at something and can holds such advantage over a sustainable period (Noe, Hollenbeck, Gerhart, \& Wright, 2007). In relation to this, job satisfaction would boost the employees' motivation in the long-term and keep them in their positions. Without job satisfaction, the organization has to contend with the recruitment costs stemming from turnover (Mudor \& Tooksoon, 2011). Majority of studies concentrated on the outcomes of human resource in terms of commitment of employee, employee satisfaction, and employee retention in the face of the dynamic business environment. Organizations are making a shift towards considering human resource as a valuable asset, wherein knowledge, skills and abilities of workers is viewed as a source of competitive advantage. Armstrong (2010) revealed that motivation, commitment and job satisfaction, individually or together, will be higher, when positive experience of human resource practices are perceived by people and this would lead to an able workforce, motivated behaviors and participation opportunities. In Jordanian private organizations, there is considerable number of employees working, with majority of them not satisfied with their work's human resource practices and their job positions. In this regard, private organizations are often secretive about details on the effect of human resource practices on their employees' satisfaction. Moreover, private organizations are characterized by high turnover, with some employees often searching for jobs in rival organizations, including public organizations. However, private organizations with effective human resource practices, facilitating a good working environment and making sure that their employees are satisfied working for them are exceptions. Each employee is inclined towards perceiving job satisfaction, but often times, human resource practices are handled in a way that employee job satisfaction is not viewed at the forefront (Javed, Rafiq, Ahmed, \& Khan, 2012). Owing to the scarcity of efficient human resources practices, satisfaction among employees has decreased and eventually, this influences their organizational commitment (Majumder, 2012).

Although human resources practices are expected to have a direct influence on job satisfaction, empirical findings that support this fact are still few and far between (Omar, Salessi, \& Urteaga, 2017). Moreover, while majority of studies including (Igbal et al., 2013; Javed et al., 2012; Syed \& Yan, 2012) focused on examining the human resource practices effect on job satisfaction among employees in the public sector (developed and developing countries), few studies have tackled the private sector, particularly in the Jordanian hotel industry. In other words, studies are lacking in the role of human resource management practices in the Jordanian hotel industry. Therefore, the present study is an attempt to minimize the literature gap concerning the role of human resource management practices in job satisfaction, with a special focus on Jordanian hotels. 


\section{Literature Review and Hypotheses}

\subsection{Job Satisfaction}

The top extensively used citation of the job satisfaction definition was provided by Locke (1976) who referred to it as a pleasing emotional state that stems from the individual's evaluation of his job (Haque \& Taher, 2008). Job satisfaction is also referred to as the attitude of the individual towards his/her job (Ray \& Ray, 2011) and there is a significant relationship between motivation and job satisfaction (Niazi, 214). Several factors including employees' needs and desires, social relationships, style and management quality, job design, compensation, working conditions, perceived long-term opportunities and perceived alternative opportunities elsewhere are deemed to be the job satisfaction determinants (Niazi, 214). Moreover, studies (Aziri,2011; Gangai \& Agrawal, 2015) reported that job satisfaction has a significant effect on the organizational commitment, turnover, absenteeism, tardiness, accidents and grievances of employees. In relation to the above, a satisfied workforce can bring about increased productivity of the organization through less disruption stemming from absenteeism/turnover, few incidences of destructive behavior and minimal medical costs (Ray \& Ray, 2011).

\subsection{Human Resource Practices}

Human resource management comprises of the policies and practices that entail the carrying out of human resource aspects of management, which encapsulates recruiting and selecting employees, training and development, human resource planning, appraisal of employee performance, compensation, job analysis and labor relations (Dessler, 2007). Moreover, according to Noe, Hollenbeck, Gerhart and Wright (2007), human resource management consists of the policies, practices and systems affecting the behavior, attitude and eventually performance of the employees. Wright et al. (2003) referred to human resource management practices as the activities of the organization that is directed towards the management of human capital, and ensuring that such capital is directed towards achieving the objectives of the organization. Such practices can thus be described as a set of interrelated practices that facilitate an environment that generates high employee commitment and boosts performance, and ultimately, leads to the optimum performance of the organization.

\subsubsection{Recruitment and Selection}

Recruitment and selection practices consist of employment planning and forecasting, recruiting, and selecting employees. One of the most important human resource practices in the service industry is hiring the right person (Brindusoiu, 2013). Recruitment and selection is the most critical function among management practices because the quality of an organization's people has a significant impact on long term success (Ulrich, 1997). Hiring the right person in the first place can save much of managers' training effort and time. High retention rates and decrease of turnover rates is also possible by hiring the right people (Brindusoiu, 2013), indicating that recruitment and selection practice can be said to lead to financial success and in turn improve organizational performance. 


\subsubsection{Training and Development}

Training and development is defined by Aswathappa (2008) as a systematic process through which expertise is developed in an individual mainly for performance enhancement. In order to improve employees' skills and knowledge for both their current jobs and in preparation for the future job challenges, an organization needs to implement strategic training and development programs. The purpose of employee development is to develop human potential to assist organizations and other individuals to achieve their objectives. Employers must develop their employees' knowledge, skills, attitudes and values in order to realize their full potential. In order for training to be effective, organizations need to identify training needs. Training need assessment is defined as the process of identifying the needs of the organization. Whether or not the organization's needs, objectives and problems can be or addressed by training its employee is the aim of such assessment (Arthur, Bennett, Edens, \& Bell, 2003).

\subsubsection{Performance Appraisal}

Performance appraisal is a process of evaluating employees' job performance against a particular standard, and then communicating that information to those employees (Mathis \& Jackson, 2008). Basically performance appraisal has become a more crucial part of a superior tactical strategy in a competitive business environment. According to Ray and Ray (2011), performance appraisal is typically seen as having dual purposes: administrative; comprising such action as determining job assignments, raises, promotions and termination; and developmental, consisting of providing feedback, coaching and identifying training needs.

\subsubsection{Compensation}

According to Darlington (2005), compensation system is referred to as a framework of paying employee back based on their participation and productivity which resulted in successful performance of the organization, and the rewards are normally in the form of pay, commissions, bonuses and other incentives. It is argued that in today's organizations treat compensation systems more than a means to secure employment but rather as a means of enhancing organizational performance. In addition to using it to attract, retain and motivate employees, employers should also consider it as a means of implementing strategy to support organizational culture (Dessler, 2007).

\subsubsection{Employee Participation}

The practices of participative establishment have been acknowledged as suitable and effective means to optimize the competitiveness of organizations (Zwick, 2004). Employee participation practice is essentially to enable employees to contribute to decision making and work processes and to give them higher independence and control over job responsibilities and strategy of work (Irawanto, 2015). As this practice takes advantage of the specific knowledge employees have about their own work processes and combines the skills and expertise of a group of workers (Syed \& Yan, 2012), employees participating in decision making can more effectively harmonize production, and will get rid of hindrance or disruption of production process. Finally, autonomous employees may be able to diminish 
waste, inventories and inefficiencies (Cappelli \& Neumark, 2001).

\subsection{Relationship between HR Practices and Job Satisfaction}

Human resource practices and job satisfaction have been investigated extensively in different countries all over the globe and it is assumed that a relationship exists between the two variables (Islam, Bangish, Muhammad, \& Jehan, 2016). The belief is such that sound human resource practices generally lead to high job satisfaction level, and enhanced performance of the organization (Javed et al., 2012). Many researchers have investigated empirically the effects of human resource practices on job satisfaction (e.g., Khanna \& Sehgal, 2016; Oyeniyi, Afolabi \& Olayanju, 2014; Ray \& Ray, 2011; Werku, 2015 ) and generally found a positive impact. For instance, Ray and Ray (2011) examined the influence of human resource practices on job satisfaction of 17 small and medium manufacturing firms in India. Human resource practices were measured by five dimensions namely, training and development, performance appraisal, participation, compensation, and empowerment. The study revealed that human resource practices have a positive impact on job satisfaction. Another study, Oyeniyi, Afolabi and Olayanju (2014) examined the influence of human resource practices on job satisfaction in Nigeria. Human resources practices were measured in terms of compensation, training, supervisory role, promotion, and performance evaluation. The study shows the positive relationship between human resource practices and job satisfaction. In a later study, Niazi (2014) investigated the influence of human resource practices on job satisfaction in Pakistan. Six dimensions of human resource practices were examined. They were training and development, compensation and benefits, performance appraisal, promotion, opportunities for growth, and respect and integrity. The results indicated a positive relationship between human resource practices and job satisfaction. In Ethiopia, Werku (2015) examined the effects of human resource practices on job satisfaction. The human resource practices considered were training and development, recruitment and selection, compensation, and performance appraisal. The regression result shows that all human resource practices have a significant positive impact on job satisfaction. In a recent empirical study khanna and Sehgal (2016) examined the effects of human resource practices on job satisfaction in private sector Banks. The human resource practices included, training and development, performance appraisal, compensation, team work, and employee participation. The study showed that the human resource practices has significant impact on job satisfaction. Although different researchers have studied different sets of human resource management practices, most of them agree that certain practices are important in generating high job satisfaction. five dimensions are identified for measuring human resource management practices from past studies (e.g., Khanna \& Sehgal, 2016; Oyeniyi, Afolabi \& Olayanju, 2014; Werku, 2015). They are categorized as functional dimensions which include recruitment and selection, training and development, performance appraisal, compensation, and employee participation. They are considered to have a great impact on obtaining, motivating, and retaining employees, and they are responsible for improving continual competitive advantage (Pfeffer, 1995). On the basis of the argument of the empirical evidence, the following hypotheses is offered:

H1: Recruitment and selection positively influences job satisfaction. 
$\mathrm{H} 2$ : Training and development positively influences job satisfaction.

H3: Performance appraisal positively influences job satisfaction.

H4: Compensation positively influences job satisfaction.

H5: Employee participation positively influences job satisfaction.

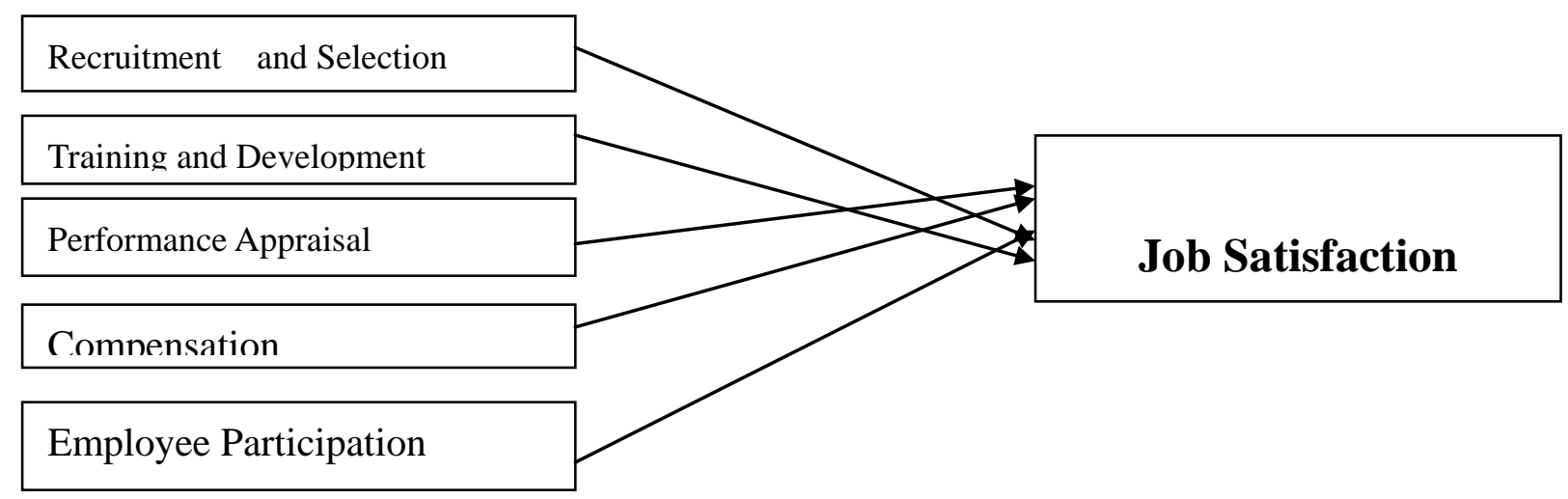

Figure 1. Study framework

\section{Methodology}

Self-designed structured questionnaire was used to collect data from respondents. Purposive sampling was employed to select eight (8) hotels, such as Intercontinental Amman, Marriott Amman, Regency Palace Amman, Le Meridien Amman, Four Seasons Hotel Amman, Holiday Inn Amman, Grand Hyatt Amman, Crown Plaza Amman while simple random sampling method was used to select (15) respondents from each hotel totaling (120) as sample size. The present study used purposive random sampling procedure to select employees from non managerial level. All questions related with human resource practices and job satisfaction were measured on 5 point likert scale which are strongly disagree (1), disagree (2), neutral (3), agree (4) and strongly agree (5). The measurement of human resource practices were adopted from several sources because none of the literature reviewed thus far has taken into account all the variables required. Recruitment and selection, training and development, performance appraisal, and compensation were adopted from Rathnaweera (2010), while employee participation were adopted from Delery and Doty (1996). Job satisfaction questionnaire was adopted from Choo and Bowley ( 2007). Overall, the survey questionnaire consists of 3 sections. The respondents were requested to provide information on demographic profile such as gender, age, level of education, experience, duration in current organization in Section A. The following Section B captures respondent's opinion on human resource practices such as recruitment and selection (6 items), training and development (5 items), performance appraisals (4 items), compensation (4 items) and employee participation (4 items). Subsequently, Section C requests respondent's opinion pertaining to job satisfaction (6 items). 


\section{Analysis and Results}

\subsection{Profile of Respondents}

The sample study analysis indicates that majority of the respondents constituted male respondents $(77.5 \%)$, with the remaining $(22.5 \%)$ as females. As for their age range, majority of the respondents (45\%), were 31-40 years of age while a few (3.3\%) were 51 years old and above. Moreover, over half of the respondents (64.2\%) held bachelor's degrees, indicating that education level is a crucial factor in hotel employment positions. For work experience, $(36.7 \%)$ of respondents have 6 and 10 years of work experience followed by 11 and 15 years of experience (30.8\%), 5 and less years of experience (22.5\%), and finally 16 and above years of experience $(10 \%)$. Lastly, in the current organization, majority of the respondents had 6-10 years of experience (35.8\%), whereas the remaining had 11-15 years of experience (28.3\%), 1-5 years of experience (26.7\%), and 16 years of experience and over (9.2\%).

\subsection{Goodness of Measures}

\subsubsection{Factor Analysis}

Table 1. Summary of Factor Analysis for Human Resource Practices Construct

\begin{tabular}{|c|c|c|c|c|c|}
\hline Items & 1 & 2 & 3 & 4 & 5 \\
\hline $\begin{array}{l}\text { Factor 1: Recruitment and Selection } \\
\text { 1. The HR department constantly chooses the suitable candidate in the } \\
\text { recruitment process. } \\
\text { 2. Selection and recruitment process is done fairly and without discrimination } \\
\text { 3. Good recruitment and selection process will increase the quality of an } \\
\text { employee. } \\
\text { 4. I believe that HR is to select right employee based on their ability and } \\
\text { qualification. }\end{array}$ & $\begin{array}{r}784 \\
833 \\
8 \\
846 \\
686^{\circ} \\
.\end{array}$ & $\begin{array}{r}288 \\
212 \\
168 \\
277\end{array}$ & $\begin{array}{l}084 \\
064 \\
089 \\
121\end{array}$ & $\begin{array}{r}033 \\
223 \\
0 \\
084 \\
\\
134\end{array}$ & $\begin{array}{l}134 \\
091 \\
118 \\
172\end{array}$ \\
\hline $\begin{array}{l}\text { Factor 2: Training and Development } \\
\text { 1. Your hotel give appropriate training and induction upon commencement. } \\
\text { 2. All training given is related with my tasks. } \\
\text { 3.My skills and knowledge provided is enough to make me a better employee. } \\
\text { 4. I believe that training and coaching important to employee pursue job } \\
\text { satisfaction. }\end{array}$ & $\begin{array}{l}188 \\
232 \\
268\end{array}$ & 072 & $\begin{array}{l}269 \\
232\end{array}$ & $764^{\circ}$ & $\begin{array}{l}245 \\
224 \\
314 \\
257\end{array}$ \\
\hline
\end{tabular}


Factor 3: Performance Appraisal

1. Your hotel have regularly scheduled employee- performance appraisal periods for employees.

2.Your performance is more often measured with objective quantifiable results (measure performance).

3. Your manager/superior handle performance appraisal without biasness/ favoritism.

4. The duration of performance appraisal reviewed is sufficient.

\section{Factor 4: Compensation}

1. Your hotel have a compensation/ benefits system that is communicated to employees.

2.Your hotel offers an attractive compensation/ benefits package compare to other establishments nearby.

3. Your hotel have a health and related benefits that is communicated to employees.

\section{Factor5: Employee participation}

1. Employees in their jobs are allowed to make many decisions.

2. Employees in their jobs are often asked by their supervisor to participate in decisions.

3. Employees are provided the opportunity to suggest improvements in the way things are done.

4. Managers keep open communications with employees in their jobs.

\begin{tabular}{|c|c|c|c|c|}
\hline 154 & 388 & 768 & $66^{0}$ & 042 \\
\hline 320 & 233 & 744 & 214 & 318 \\
\hline 075 & 140 & 745 & 046 & 078 \\
\hline 138 & 189 & 764 & 078 & 126 \\
\hline 212 & 172 & 146 & 244 & 754 \\
\hline 164 & 302 & 194 & 113 & 785 \\
\hline 121 & 211 & 396 & 174 & 766 \\
\hline 312 & 805 & 082 & 121 & 278 \\
\hline 285 & 802 & 024 & 136 & 184 \\
\hline 451 & 694 & 077 & 272 & 146 \\
\hline 212 & 788 & 228 & 084 & 008 \\
\hline
\end{tabular}

Eigenvalue

Percentage of Variance Explained $=64.566 \%$

Kaiser-Meyer-Olkin $=.685$

Bartlett's Test of Sphericity Approx. Chi Square $=814.824 ; \mathrm{df}=46 ; \mathrm{Sig}=.000$

KMO and BTS were used to determine whether factor analysis was appropriate for human resource practices. Result is shown in Table 1.1, which indicates that the KMO value was .685, which is 'mediocre' according to Kaiser (1974), as it was above .60. The BTS value was very large $(814.824)$ and significant $(\mathrm{p}<.001)$.

There are five dimensions to the human resource practices as depicted in Table 1.1; first, recruitment and selection, under which six items are covered. From the six items S3 and S5 
were dropped owing to the results of the exploratory factor analysis, as result of which four items remained (S1, S2, S4 and S6) for analysis. The entire four items loadings exceeded 0.50 , indicating that they are significantly correlated to the factor, with loadings ranging from 0.687 to 0.846 , as established by Hair et al. (2006). In other words, the four items successfully measure recruitment and selection. The second dimension is training and development, under which five items are covered and out of the total items, one item (T4) was dropped owing to low loadings. Four loadings remained (T1, T2, T3 and T5) for analysis and four items loadings exceeded $0.50(0.734-0.818)$, which indicates that they significantly correlated to the factor itself (Hair et al., 2006), and that the four items were successful in measuring training and development variable. Moving on to performance appraisal variable, there were four items that were exposed to exploratory factor analysis, after which no differences were noted between the original items and the new items and thus, the same labels were used for each factor. The four items loadings exceeded 0.50 (0.744-0.768), indicating that they had significantly correlated with the factor itself (Hair et al., 2006). With regards to compensation, it was measured by four items but 3 out of $4(\mathrm{C} 1, \mathrm{C} 3$ and $\mathrm{C} 4)$ were confirmed to be suitable for factor analysis with one item (C2) dropped. The three factors loaded highly (Hair et al., 2006) with values ranging from 0.754 to 0.785 , indicating that all three were successful in measuring compensation. Employee participation was measure by four items, and following the exploratory analysis, not differences were found between the original items and the new ones and therefore, the same labels were employed for each factor. The loadings of all four items exceeded 0.50 (0.694-0.805), which shows that all significantly correlated to the factor itself (Hair et al., 2006). The four items were deemed to effectively measure employee participation.

Table 2. Summary of Factor Analysis for Job Satisfaction Construct

\begin{tabular}{l|c}
\hline \multicolumn{1}{c|}{ Items } & Comp \\
& 0nent \\
\hline 1. My work environment is comfortable. & $\mathbf{. 8 1 2}$ \\
2. My supervisor frequently acknowledges, when I perform a good job. & $\mathbf{. 7 7 4}$ \\
3. My values are very similar with this organization. & $\mathbf{. 7 8 2}$ \\
4. I am willing to perform exceeding expectation for the organization's success. & $\mathbf{. 6 5 4}$ \\
5. I am proud to inform others that I am employed by this organization. & $\mathbf{. 7 4 2}$ \\
6.My co-workers are considered as my friends. & $\mathbf{. 7 5 2}$ \\
\hline
\end{tabular}

Eigenvalue

Percentage of Variance Explained $=60.228 \%$

Kaiser-Meyer-Olkin $=.763$

Bartlett's Test of Sphericity Approx. Chi Square $=278.614 ; \mathrm{df}=10 ; \mathrm{Sig}=.000$ 


\section{Macrothink}

International Journal of Human Resource Studies

ISSN 2162-3058

2018, Vol. 8, No. 4

Similarly, job satisfaction was measure by six items, and following the exploratory analysis, not differences were found between the original items and the new ones and therefore, the same labels were employed for each factor. The loadings of all six items exceeded 0.50 (.654 to .812), which shows that all significantly correlated to the factor itself (Hair et al., 2006). The six items were deemed to effectively measure job satisfaction.

\subsubsection{Reliability Analysis}

Table 3. Reliability Analysis

\begin{tabular}{l|c|c}
\hline \multicolumn{1}{c|}{ Variable } & $\begin{array}{c}\text { No. of } \\
\text { items }\end{array}$ & $\begin{array}{c}\text { Cronbach's } \\
\text { Alpha }\end{array}$ \\
\hline Recruitment and Selection & 4 & .80 \\
Training and Development & 4 & .74 \\
Performance Appraisal & 4 & .79 \\
Compensation & 3 & .82 \\
Employee Participation & 4 & .76 \\
\hline Job Satisfaction & 6 & .84 \\
\hline
\end{tabular}

The reliability of the questionnaire was tested using Cronbach's Alpha to show the internal consistency of the items been studies in the questionnaire. The result shows that, the range of the values of Cronbach's Alpha for all the variables was 0.74 to 0.84 and considered reliable.

\subsection{Regression Analysis}

This section deals with the hypotheses in the present study which predicts that five human resource dimensions (recruitment and selection, performance appraisal, training and development, compensation, and employee participation) have positive relationship with the job satisfaction. In regression analysis, absolute beta values were utilized to compare contribution of each dimension of human resource practices to the dependent variable (Pallant, 2007).

Table 1.4 shows that the model was generally significant $(\mathrm{F}=7.89$, Sig $=.000)$. The results indicate that a value of $\mathrm{R} 2$ is .169 , indicating that $16.9 \%$ of the variance in job satisfaction was explained significantly by a number of independent variables i.e. recruitment and selection, performance appraisal, training and development, compensation, and employee participation. 
Table 4. Result of Regression Analysis HRP with Job Satisfaction

\begin{tabular}{l|c|c|c|c|c}
\hline \multirow{2}{*}{ Independent variables } & \multicolumn{2}{|l|}{$\begin{array}{l}\text { Unstandardized } \\
\text { beta }\end{array}$} & $\begin{array}{c}\text { Standardized } \\
\text { beta }\end{array}$ & $\mathbf{t}$ & Sig. \\
\cline { 2 - 5 } & \multicolumn{2}{|l|}{ B } & Std. error & & \\
\hline (Constant) & 1.69 & .266 & & 5.189 & .000 \\
\hline Recruitment and Selection & .135 & .052 & .158 & 2.488 & .012 \\
\hline Training and development & .164 & .054 & .187 & 3.144 & .002 \\
\hline Performance appraisal & .152 & .064 & .156 & 2.188 & .019 \\
\hline Compensation & .221 & .069 & .219 & 3.159 & .001 \\
\hline Employee participation & .124 & .062 & .123 & 2.141 & .026 \\
\hline
\end{tabular}

Note. $R^{2}=.169, \mathrm{~F}=7.89$, Sig. $=.000$

Table 1.4 shows that all the dimensions of human resource practices were significantly related to job satisfaction. Specifically, compensation contributed the most $(B=.219, \mathrm{p}$ $=.001)$, followed by training and development $(\beta=.187, \mathrm{p}=.002)$, followed by recruitment and selection $(\beta=.158, p=.012)$, followed by performance appraisal $(\beta=.156, p=.019)$ and employee participation $(\beta=.123, \mathrm{p}=.026)$. In this study, therefore, all dimensions of human resource practices made a unique and statistically significant contribution to the prediction of job satisfaction. Hence, H1, H2, H3, H4, and H5 were supported.

\section{Discussion}

The current study examined the influence of human resource practices on job satisfaction among Jordanian hotels employee. The current study used five human resource practices such as recruitment and selection, training and development, performance appraisal, compensation, and employee participation. On the basis of the findings of this study, it can be concluded that all human resource practice dimensions have positive influence on job satisfaction among Jordanian hotels employee. The current study hypothesized that recruitment and selection positively influences job satisfaction. Result showed that recruitment and selection was statistically significant in predicting job satisfaction. This finding appears to be consistent with previous studies that revealed positive relationship between recruitment and selection and job satisfaction (Ray \& Ray, 2011; Werku, 2015). This positive significant relationship means that a good staffing system will ensure the right person with the right experience, knowledge, skills and ability is hired to fit with the job demand. When the abilities of a person match with the demands of the job, it will improve the person's job satisfaction. The 
present study indicates that training and development related to job satisfaction. This finding is in accordance with previous studies by (Khanna \& Sehgal, 2016; Niazi, 2014). One possible explanation for this may be because the skills and knowledge that employees receive through training program is perceived beneficial to them in achieving better performance. Training and development is any effort to improve current of future employees' skills, abilities and knowledge. Thus, to increase job satisfaction, the management should continuously conducting training on related skills and knowledge which are necessary to the organization and are required to be acquired by the employees to achieve organizational goals. In this study, performance appraisal was also found related with job satisfaction. This finding supported previous studies conducted by (Khanna \& Sehgal, 2016; Niazi, 2014; Werku, 2015). Since performance appraisal often leads to pay raise, promotion and training, it is not surprise to find why performance appraisal influence employee job satisfaction. However, to use performance appraisal as a way to improve employee job satisfaction, the management must ensure the performance appraisal system is fair and measured relevant parts of the job. Additionally, the current study reported a significant influence of compensation on job satisfaction. The finding obtained in the currents study appears to be consistent with other scholars who found positive relationship between employee compensation and job satisfaction (e.g., Niazi, 2014; Ray \& Ray, 2011). Finally, the current study showed a positive relationship between employee participation and job satisfaction. The present result is thus in line with previous findings (Khanna \& Sehgal, 2016).

\section{Theoretical and Managerial Implications}

The findings from this study have several important implications to both practice and theory, as discussed below.

\subsection{Theoretical Implications}

This study examines potential job satisfaction determinants namely, human resource practices namely, recruitment and selection, training and development, performance appraisal, compensation and employee participation. On the basis of the results, the job satisfaction level among employees ranged from high, moderate and slightly low according to the factors examined. This result is aligned with prior studies and practitioners' feedback in that effective human resource practices can lead to enhanced job satisfaction, and in turn, enhanced performance of the organization (Syed \& Yan, 2012). The combined enhancement of human resource practices, particularly with a focus on recruitment and selection, training and development, performance appraisal, compensation, and employee participation can significantly influence organizational success, and enhance employee satisfaction.

\subsection{Managerial Implications}

The findings showed that management can facilitate the enhancement of organizational commitment among employees by enhancing their satisfaction via high performance human resource practices including training and development, compensation and employee participation. A good way of tackling this issue is to enhance employee-staff interaction through meetings and topics brainstorming and discussions that concerns it. Interviews can 
also be conducted with employees to identify their views on the ability of management to resolve the issue. Organizational variables changes like pay scales, employee participation in developing policies, and performance appraisal could be directed and developed towards supporting organizational commitment and job satisfaction of employees. In the context of Jordanian hotels, recruitment and selection, training and development, performance appraisal, compensation and employee participation are not viewed as mechanism to improve the performance of employees and therefore, this study examines these variables as predictors of job satisfaction.

\section{Limitations and Future Research}

This research has some limitations. First, the research focuses specifically on the hotels sector in Jordan with only eight hotels and 120 employees surveyed. Future research should include a larger sample size as well as a consideration of different industries. Second, the research focus is only on five human resource practices (i.e. recruitment and selection, performance appraisal training and development, compensation, and employee participation). The future studies should include more human resource practices for a more complete analysis because it can give broader picture towards manager to decide which practices can lead employee job satisfaction. Third, because this study employed the quantitative method in both design and analysis, the collected information is limited to the responses in the questionnaire. On the other hand, a qualitative method could add to further insights and understanding of the problem setting. In addition to this, a more meaningful determination could be brought about by combining the use of both qualitative and quantitative methods as they are complementary to each other.

\section{References}

Armstrong, M. (2010). Armstrong's essential human resource management practice: A guide to people management. USA: Kogan Page Limited.

Arthur, W., Bennett, W., Edens, P., \& Bell, S. (2003). Effectiveness of training in organizations: A meta-analysis of design and evaluation features. Journal of Applied Psychology, 88(2), 234-245. https://doi.org/10.1037/0021-9010.88.2.234

Aswathappa, K. (2008). Human resource management: Text and cases (2nd ed.). Delhi: McGraw-Hill Publishing Company Limited.

Aziri, B. (2011). Job satisfaction: A literature review. Management Research and Practice, 3(4), 77-86.

Brindusoiu, C. (2013). Recruitment and selection in services organizations in Romania. Social and Behavioral Sciences, 92, 112-116. https://doi.org/10.1016/j.sbspro.2013.08.645

Cappelli, P., \& Neumark, D. (2001). Do" high-performance" work practices improve establishment-level outcomes. Industrial \& Labor Relations Review, 54(4), 737-775.

Choo, S., \& Bowley, C. (2007). Using training and development to affect job satisfaction within franchising. Journal of Small Business Enterprise Development, 14(2), 339-352. 
https://doi.org/10.1108/14626000710746745

Darlington, H. (2005). The basics of a good compensation program. Supply House Time. March, 74-75.

Delery, J., \& Doty, D. (1996). Modes of theorizing in strategic human resource management: Tests of universalistic, contingency, and configurational performance predictions. Academy of Management Journal, 39(4), 802-835. https://doi.org/10.5465/256713

Dessler, G. (2007), Human Resource Management (5thed.). Prentice-Hall, Englewood Cliffs, NJ.

DOS (2016). Department of Statistics in Jordan. Retrieved January 28, 2016, from http://www.dos.gov.jo/sdb_pop/sdb_pop_a/tech_2015.pdf.

Gangai, N., \& Agrawal, R. (2015). Job satisfaction and organizational commitment:Is It important for employee performance. International Journal of Management and Business Research, 5(4), 269-278.

Hair, J., Black, W., Babin, B., Anderson, R., \& Tatham, R. (2006). Multivariate data analysis (6th ed.). New Jersey: Prentice Hall.

Haque, M., \& Taher, M. (2008). Job characteristics model and job satisfaction: Age, gender and marital status effect. Paper presented at the 7th International Conference on Ethics and Quality of Work-life for Sustainable Development, Harvard Business Review, (2), 53-62.

Holjevac, I. A. (2003). A vision of tourism and the hotel industry in the 21st century. International Journal of Hospitality Management, 22(2), 129-134. https://doi.org/10.1016/S0278-4319(03)00021-5

Iqbal, H. K., Malik, M. E., \& Ghafoor, M. M. (2013). Impact of HR practices on job satisfaction: An empirical evidence from corporate sector of Punjab- Pakistan. Interdisciplinary Journal of Contemporary Research in Business, 5(2), 442-454.

Irawanto, D. W. (2015). Employee participation in decision-making: Evidence from a state-owned enterprise in Indonesia. Global Business Review, 20(1), 159-172.

Islam, Z. U., Bangish, S. B., Muhammad, H., \& Jehan, A. S. (2016). The impact of HR practices on job satisfaction: A case study of hotel industry in Pakistan. Journal of Asian Finance, Economics and Business, 3(1), 43-48. https://doi.org/10.13106/jafeb.2016.vol3.no1.43.

Javed, M., Rafiq, M., Ahmed, M., \& Khan, M. (2012). Impact of HR practices on employee job satisfaction in public sector organizations of Pakistan. Interdisciplinary Journal of Contemporary Research in Business, 4(1), 348-363.

Kaiser, H. F. (1974). An index of factorial simplicity. Psychometrika, 39(1), 31-36. https://doi.org/10.1007/BF02291575

Khanna, P., \& Sehgal, M. (2016). A study of HRM practices and its effect on employees job 
satisfaction in private sector Banks with special reference to ICICI Banks in Ludhiana. International Journal of Management, 4(7), 36-43.

Locke, E. (1976). The handbook of industrial and organizational psychology. New York: Wiley.

Majumder, T. H. (2012). Human resource management practices and employees' satisfaction towards private banking sector in Bangladesh. International Review of Management and Marketing, 2(1), 52-58.

Mathis, R., \& Jackson, J. (2008). Human resource management (12thed.). Ohio: Thomson Learning, Inc.

Ministry of Tourism and Antiquities. (2016). Jordan National Tourism Strategy 2015-2020. Available at www.tourism.jo.

Mudor, H., \& Tooksoon, P. (2011). Conceptual framework on the relationship between human resource management practices, job satisfaction, and turnover. Journal of Economics \& Behavioral Studies, 2, 41-49.

Niazi, M. M. K. (214). Impact of human resource practices on job satisfaction: A study of textile industry of Pakistan. International Journal of Management \& Organizational Studies, $3(1), 27-31$.

Noe, R., Hollenbeck, J., Gerhart, B., \& Wright, P. (2007). Fundamentals of human resource management: Gaining a competitive advantage. New York: McGraw: Hill Companies, Inc.

Omar, A., Salessi, S., \& Urteaga, F. (2017). Impact of management practices on job satisfaction. Mackenzie Management Review, 18(5), 92-115. https://doi.org/10.1590/1678-69712017/administracao.v18n5p92-115

Oyeniyi, K. O., Afolabi, M. A., \& Olayanju, M. (2014). Effect of human resource management practices on job satisfaction: An empirical investigation of Nigeria Banks. International Journal of Academic Research in Business and Social Sciences, 4(8), 243-251.

Pallant, J. (2007). SPSS survival manual (3rded.). New York: McGraw Hill.

Pfeffer, J. (1995). Producing sustainable competitive advantage through the effective management of people. Academy of Management Executive, 9(1), 55-72.

Rathnaweera, R. R. N. T. (2010). Do HRM practices impact employee satisfaction, commitment or retention? Empirical studies of Sri Lankan public sector Banks. Unpublished Master's Thesis, University of Agder.

Ray, S., \& Ray, I. A. (2011). Human resource management practices and its effect on employees' job satisfaction: A study on selected small and medium sized iron and steel firms in India. Public Policy and Administration Research, 1(1), 22-33.

Syed, N., \& Yan, L. X. (2012). Impact of high performance human resource management practices on employee job satisfaction: Empirical analysis. Interdisciplinary Journal of 


\section{Macrothink \\ International Journal of Human Resource Studies \\ ISSN 2162-3058 2018, Vol. 8, No. 4}

Contemporary Research in Business, 4(2), 318-342.

Ulrich, D. (1997). Measuring human resources: An overview of practice and a prescription for results. Human Resource Management, 36(3), 303-320. https://doi.org/10.1002/(SICI)1099-050X(199723)36:3<303::AID-HRM3>3.0.CO;2-\#

Werku, A. (2015). The effect of selected human resource management practices on employees' job satisfaction in Ethiopian public Banks. Emerging Markets Journal, 5(1), 1-16. https://doi.org/10.5195/EMAJ.2015.64

Wright, P., Gardner, T., \& Moynihan, L. (2003). The impact of HR practices on the performance of business units. Human Resource Management Journal, 13(3), 21-36. https://doi.org/10.1111/j.1748-8583.2003.tb00096.x

Zwick, T. (2004). Employee participation and productivity. Labor Economics, 11(6), 715-740. https://doi.org/10.1016/j.labeco.2004.02.001

\section{Copyright Disclaimer}

Copyright for this article is retained by the author(s), with first publication rights granted to the journal.

This is an open-access article distributed under the terms and conditions of the Creative Commons Attribution license (http://creativecommons.org/licenses/by/4.0/). 